\title{
REGIONAL PRODUCTIVE INTEGRATION: THE LATIN AMERICAN AUTOMOTIVE INDUSTRY UNDER LAIA AGREEMENTS
}

\author{
Karla Sarmento Gonçalves de Souza, Jorge Nogueira de Paiva Britto e Marta dos Reis Castilho
}

\begin{abstract}
Since the 1980s, the auto industry has increasingly fragmented the production across national borders. Latin America has been part of the leading automakers' global strategy both as a consumer and as a regional producer. In this context, preferential trade agreements have been relevant to reduce costs and to overcome the limitations related to the size of domestic markets. Argentina, Brazil and Mexico are the region's leading automotive producers and sellers (for both the domestic market and for exports), and their auto industries show a high degree of production integration. However, they products have different destinations. While the Brazilian's and the Argentinean's products are destined to regional markets, supported by bilateral agreements under the LAIA, Mexico's production is exported to the United States, due to geographical proximity and to the dynamism of the trade with the NAFTA market. These evidenced are corroborated by the analysis of the pattern of the auto industry regional trade, which distinguishes intermediate and final goods, as well as by the estimation of intra-industry trade indexes. Imports of intermediate goods are mostly extra LAIA: in Brazil, 85\% of these imports are extra-LAIA and in Mexico they correspond to 97\%, contrasting to Argentina, where they are is only 48\%. On the export side, Mexican exports of intermediate goods are mostly extra-LAIA (98\%), contrasting with Brazil (with 34\% of exports extra-LAIA) and Argentina (with 18\% of exports extra-LAIA) which export focus on the regional market. So, these patterns suggest that while the Mexican trade and, to a lesser extent, the Brazilian trade is more linked to external partners, the Argentina trade is more prominent among partners in the region
\end{abstract}

Keywords: Automotive Industry, Production Fragmentation, Production Integration, Trade Agreement, LAIA.

JEL Classification: F15, L60

Regional Productive Integration: the LA Automotive Industry under LAIA agreements

\section{Introduction}

Global evidences show that the process of productive fragmentation is particularly relevant in the automotive industry. Since the 1980s, we observed a trend towards internationalization of productive activity of Asian companies toward the United States and Europe and then of US companies toward Mexico and Eastern Europe (BORGES, 2011). In the 1990s, we also observed a growing internationalization towards emerging economies. The establishment of regional trade agreements around the main consumer poles and the growing industrialization of emerging countries contributed to the design of the strategies and to the current configuration of the automotive industry worldwide. Although these strategies are drawn globally, the decision about the location of productive units is related to characteristics of the domestic markets. Automakers tend to adapt their models to the preferences of local consumers, deciding the location of plants considering the level of income, infrastructure and tax structure of each region (HAMAGUCHI, 2010, WOMACK, JONES and ROOS, 2004 and NISHITATENO, 2012).

At the same time, due to its impacts on the rest of the economy, its capacity to disseminate technical progress, to generate high-income jobs and to induce the development of local suppliers, the auto industry is one of the key sectors that receive special treatment of economic policies. The 2008 crisis, for example, led to an expansion of government support to the sector through business recovery programs and to incentives for the purchase of new vehicles in many countries. The importance of this sector is also evident in the 
negotiation of international trade agreements such as in $\mathrm{NAFTA}^{1}$, in the European Union ${ }^{2}$ and in Asia ${ }^{3}$ (GONÇALVES and VEIGA, 1995; CALANDRO, 2000 and CASOTTI and GOLDENSTEIN, 2008).

In Latin America the scenario has not been different. The evidences show that automotive industry in

Latin America has a relevant degree of regional productive integration and an active participation in the development of regional trade policies and in the articulation between governments, although its configuration in the region is strongly affected by the global strategies of multinational companies in the sector. In this sense, this sector diverges from the rest of manufacturing in the region that is characterized by a weak integration in global value chains and show little regional productive integration (UNCTAD, 2013). This sector has played a prominent role in intra-regional transactions and also in relation to other regional partners. It is also worth to note the number of preferential trade agreements - which exempt vehicles and parts from import taxes on the basis of the bilateral agreement (DIETER, 2007 and BORGES, 2011).

Latin American Integration Association (LAIA) emerged in the 80s with the aim to eliminate gradually the barriers to regional trade, strengthening national economies and rationalizing production and foreign trade. It is within this institutional framework that the economic relationship between the countries of the region has been deepening in recent years. Although the regional trade has grown in Latin America, one of the initial objectives of the processes of regional integration ${ }^{4}$ - the use of trade integration as a means of encouraging productive development (particularly industrial) in the region - has received little attention from policy makers. This issue - known as "regional productive integration" - has been the subject of discussions about the creation of LAIA and, later, Mercosur - has resurfaced strongly because of the recent changes in the organization of production worldwide. These changes are associated with the fragmentation of the production process, which, by dividing the production process and reorganize production in different countries, caused a significant increase in trade flows around the world from the 90s, particularly to trade flows of parts and components (or intermediate goods).

The study discusses the productive organization of the automobile industry in LAIA, focusing on the degree of articulation among national industries and on the impact of regional trade policies on this sector. The analysis aims to show in what extent and in what direction these two dimensions/aspects are associated. The paper is organized as follows. The second section provides a brief review on production fragmentation and productive integration issues. The third section presents a discussion about Trade Agreements and Regional Productive Integration, with a focus on the experience of Latin America. The fourth section shows how the auto industry has evolved in Latin America, with particular interest in LAIA countries and its trade agreements. The fifth section focus on trade policies oriented to the automotive industry, through the analysis of the tariff structure of the region. The sixth section attempts to identify key relationships between those aspects. Finally, the conclusion highlights the main contributions of the research.

\section{Productive Fragmentation and Integration: general trends}

Although widely discussed, the "regional productive integration" (RPI) is not a well defined concept nor in the academic literature nor in the business literature (HAMAGUCHI, 2010, p. 311). Reflecting this ambiguity, the concept can be used in two ways: as strictly "productive integration", concerning the integration of different stages of the production process over several sites and location, or as a "regional productive integration" that deals with the coordination of productive sector from countries involved in

\footnotetext{
${ }^{1}$ Since the 80s, some of the big US companies (Chrysler, Ford and GM) set up factories in the border region of Mexico, geared both for export and for the domestic market, in order to overcome the high protection levels prevailing at the time. This process created a basis for the agreement of NAFTA, which would eliminate the quantitative and tariff restrictions between the US, Mexico and Canada in 2003.

${ }^{2}$ Similar process happened in Europe. Through the approval of Automotive Protocol of 1989 which aimed to end the fiscal war between the member countries to attract car manufacturers. Eastern Europe was incorporated into the production process, increasing the degree of productive integration between the Europe Union countries.

${ }^{3}$ In Asia, unlike what occurred in the other two blocks, trade agreements came to formalize a process of productive integration that was already being practiced among different countries in the region, led initially by Japanese firms and then by Korean firms.

${ }^{4}$ This objective was explicit in the first LA integration initiative of the 60's - the LAFTA. As this initiative didn't attempted its economic integration goals, a more flexible agreement - LAIA - replaced it in 1980.
} 
preferential agreements. Although they can be treated autonomously, the two dimensions are strongly related, since the preferential agreements signed between those countries permit to reduce marketing costs and stimulate the articulation and the complementarities between national industries.

The productive fragmentation itself is not a new phenomenon. The novelty relies in the degree of sophistication of trade flows and in the coordination exercised at each stage of the process. The production fragmentation is a result of several factors and is strongly linked to technical aspects of each industry, being more common in modular production processes (separable by stages). This is a characteristic of the assembly industries - such as aeronautics, automotive and electronic components. Recent technological developments in several areas enabled, on one hand, the separation of the production process in different stages $^{5}$ and, on the other hand, reduced transport and transaction costs. Face to these opportunities ${ }^{6}$, Multinational enterprises (MNEs) has changed their internalization strategies, increasing its subcontracting practices and the installation of subsidiaries in different countries. Production stages or tasks were spread to several countries, under different business strategies (FDI or outsourcing), in order to exploit each country comparative or competitive advantages (HAMAGUCHI, 2010).

The productive fragmentation is closely related to the formation of Global Value Chains (GVCs). According to KAPLINSKY and MORRIS (2001) and GEREFFI and FERNANDEZ-STARK (2011) a value chain comprises all production stages of a good or service, from its conception to its physical production, including the various stages of its production process until the delivery to the final consumer and the process of recycling or disposal ${ }^{7}$. The value chain approach exceeds the production of the good itself, conceiving production as a link that adds value to the product. Thus, the steps that add value to a final good might be carried out by various companies of different nationalities. In this regard, coordination plays a key role, since it is necessary to organize the production in different locations depending on its competitive advantages.

The productive fragmentation also involves microeconomic elements. The decision between vertical integration or productive fragmentation is taken by the firm considering the cost differential between the two forms of production, seeking to exploit the possibilities of product differentiation and the economies of scale-scope (GALAR, 2012; OLIVEIRA, 2014) . OECD (2013) points out that, among the reasons that lead companies to fragment their production, the main ones involve economic gains from economies of scale and scope, the access to foreign markets, as well as to strategic assets and new knowledge. In This context, the trade-off between the cost of production and transactions is essential, as originally pointed by COASE (1937), determining the degree of vertical integration of the firm. In order to focus on activities that provide greater return, a company has to transfer their less profitable activities to other companies. But the creation of lasting and reliable relationships with suppliers also involves different costs (ARAUJO, 2013). According to JONES and KIERKOWSKI (1990), this decision is motivated by the possibility of reducing production costs, especially those associated with service link $\operatorname{costs}^{8}$ (KIMURA and ANDO, 2005).

STURGEON (2013) states that the fragmentation of production occurs through two main ways, namely through market transactions and through multinational companies, including Foreign Direct Investment (FDI) and intra-firm trade. In this context, transnational corporations have changed its role: from global producers they became global buyers. According to OLIVEIRA (2013), MNCs currently govern subcontractors and other participants in CGV, determining deadlines, quality standards and product

\footnotetext{
${ }^{5}$ Some authors agree that the automotive industry, especially the Japanese, has played an important role in technical and organizational changes at the origin of the global trade and production networks. See CASOTTI and GOLDENSTEIN (2008).

${ }^{6}$ UNCTAD (2013) highlight the decline in transport costs - reflecting a process of "containerization" and the improvements of logistics services - and the emergence of new organizational forms such as modular production and flexible manufacturing. MEDEIROS (2010) and HELPMAN (2010) highlight the importance of the revolution in information and communication technologies that led to the codification and modularization of the production (physically and geographically) facilitating the coordination of the process HILLBERRY (2011) and STURGEON (2013) point out that the emergence of new market economies at the end of the 80s, such as China, Russia, India and some Eastern European countries led to a new reorganization of the production process.

${ }^{7}$ The stages of a GVC also include the obtaining inputs, R\&D activities, production, distribution, marketing and after-sales services

${ }^{8}$ Service costs are also influenced by the controllability of the process, especially with regard to reliability, to the control of information flows and to the solution of trade disputes
} 
specifications. ${ }^{9}$ MEDEIROS (2010) stress the importance of MNCs in the process of production fragmentation due to the high administration costs and to the coordination inherent in this strategy (HELPMAN, 2011 STURGEON, 2013).

Is it possible to promote the "productive regional integration” through preferential agreements? Trade liberalization agreements are particularly important to the fragmentation process and its spread over several countries as it reduces transaction costs directly - by suppressing tariffs and non tariffs barriers - but also indirectly when facilitating trade between partners. In the case of regional productive integration, the fragmentation can be further developed with the implementation of preferential agreements. To the extent that the costs associated with trade gained importance, trade agreements facilitate the consolidation of value chains in an economically integrated area (HAMAGUCHI, 2010; MACHADO, 2010). The gains generated could be static - resulting in the possibility of trade creation in a Vinerian sense - or dynamic - involving economies of scale generated by the market expansion, learning gains promoted by new productive relationships, stimulus to research and development and to the increase of FDI flows, among others.

DULLIEN (2010) argues that the productive integration based on preferential agreements can be an effective tool to promote equitable development of economies in a particular region. According to the author, there is no opposition between productive integration and trade integration, arguing that they are complementary and should occur concomitantly. KOSACOFF and LÓPEZ (2008) also argue that these agreements and the resulting integration of countries in global value chains may be part a "catching-up" strategy. At the firm level, they can stimulate learning processes and improve their competitiveness. In the case of developing countries, it is believed that the preferential agreements would provide greater dynamism to those economies.

ESTEVADEORDAL, BLYDE and SUOMINEN (2013) highlight the role of the reduction of tariffs generated by preferential trade agreements (PTAs) as an important stimulus to the establishment of regional production networks. Since the fragmentation of the production processes requires that a good cross the border several times, high trade tariffs would increase the cost of the final product ${ }^{10}$. According to STURGEON ET AL (2013), the CGV have developed in a context of decreasing trade barriers, followed by WTO ascension and by the implementation of Washington Consensus policies. However, it was observed that the emerging economies that grew most were those that carried out policies that stimulate a better external insertion, whether for specific industries, through import substitution or through an export oriented pattern $^{11}$.

Based on this assumption, the OECD (2013) proposed a "well adapted trade policy" from the perspective of GVC. Among the main recommendations, it highlights the importance of stimulating imports to permit the growing of exports. From the perspective of the GVC, because part of the production is imported to be processed and exported, the presence of import tariffs would be a kind of tax on exports, making it difficult the insertion in a GVC. OECD (2013) report emphasize the importance of adopting trade facilitation measures ${ }^{12}$, as well as those to improving the transport and logistics services. In addition, it emphasizes the importance of deepening trade agreements, including not only trade in goods but also facilitating trade in services and the movement of people, capital and technologies, addressing also other issues such as intellectual property.

\footnotetext{
${ }^{9}$ The OLI approach (ownership, location, and internalization) argues that a location need to have advantage in three areas to install a branch of a multinational. The first is the advantage of the property, which relies on specific assets. Another advantage would be the location itself, permitting a non onerous trade between subsidiary and the mother company, allowing access to inputs at low cost, with reduced taxes and tariffs. The third advantage refers to the internalization, in a way that the matrix must maintain the control over the subsidiary, reducing costs through the use of international licensing and joint ventures (HELPMAN, 2011).

${ }^{10}$ FUGAZZA and NICITA (2010) empirically tested the importance of PTAs through a Gravitational Model and concluded that they improved market access and that they do not have a discriminatory character, in part due to the proliferation of increasingly broad agreements.

${ }^{11}$ However, these policies would not be the best alternative for the reality of GVCs, and even today, most emerging countries lack policies well adapted to an effective inclusion in GVCs

${ }^{12}$ In the context of economies integrated in GVCs, the issue of rules of origin should be less restrictive and trade agreements should lead to harmonization of technical regulations and standards.
} 
UNCTAD (2013) points out that trade policy may affect the insertion of companies in GVCs. First, excessive high rates may lead to higher inputs, making the country less attractive for investment. In addition, the unfavorable market conditions would make these countries less attractive to manufacturers, due to the difficulty in distributing the final products. For this reason, companies often choose to settle in countries belonging to preferential trade agreements with tax exemptions. In this context PTAs facilitate access to the country and influence the location of the production process. However, current trade policies still have limitations, mainly the tendency to be directed to the final products. The report recommends the establishment of low rates for intermediate goods, which provides incentive for their imports, following by with high rates for final goods, which generates incentives for manufacturers to locate production in these countries, especially when they have a large consumer market or permit an access to other markets . Other mechanisms that would make a country more attractive would include the creation of Export Processing Zones and Drawback systems targeted for the purchase of intermediate goods. OECD (2013) also emphasizes the importance of a policies oriented to a liberalization of FDI flows, given the important role of MNCs to processes of productive fragmentation. To implement these policies, all the stages of the production chain might be considered, involving not only manufacturing activities.

\section{Trade Agreements and Regional Productive Integration: a focus on Latin America}

For developing countries, such as Latin American countries, the inclusion in GVCs is an important part of development strategies led by exports, representing an opportunity to insert small and medium-sized local firms in the international market. Through these strategies, developing countries reap the benefits of economies of scale and scope and diversify their exports to higher value-added products. In addition, it may represent a form of learning for local businesses, allowing an access to new technologies and permitting to get imports at more competitive prices. All these externalities would increase the attractiveness of these economies to Foreign Direct Investments (STURGEON and MEMEDOVIC, 2011; WEF, 2012; UNCTAD, 2013b; OECD, 2013). GEREFFI and FERNANDEZ-STARK (2011) and STURGEON (2013) emphasize that the insertion in GVCs can generate a spillover effect to the rest of the economy through an efficient combination of domestic and imported inputs, creating new and better jobs that can have a positive impact on the reduction of unemployment and poverty. However, these benefits depend on how these economies will be inserted In GVCs. Depending on this insertion, companies can get "stuck" (lock-in) in a step that adds little value based on static competitive advantages. ${ }^{13}$ As shown by the "smile curve" and discussed by MILBERG and WINKLER (2011), the position in GVC is crucial to determine how much value added is appropriate by the firm and the country. This position defines a process of "social upgrading" that includes not only an economic upgrading connect to the increase of international trade but also on the impacts in for living standards, including wages, work conditions, economic rights, gender equality, technological transfer and economic security

The productive integration is more a regional phenomenon, especially in East Asia, Europe and North America (MEDEIROS, 2010). ECLAC (2013) also highlights that despite the cost reductions in transport and communication costs, the distance is still a major obstacle and, therefore, the GVCs tend to be structured at the regional level. In addition to the factors already mentioned, ECLAC (2013) also highlights the importance of an appropriate regulatory environment for the formation of GVCs, ensuring a free flow of goods, information, people and capital and guaranteeing the ownership rights to tangible and intangible goods generated by EMN. This "need" has led countries to establish deeper preferential arrangements, especially North-South agreements, which go beyond the mere tariff reduction, providing a convergence of trade regulations, According to this literature, the deepening of liberalization would be responsible for a

\footnotetext{
${ }^{13}$ In these cases, its insertion does not provide long-term benefits. In addition, the relocation of jobs required by the insertion in GVC can lead to unemployment and wage cuts. In addition, profits from subsidiaries in these countries tend often to return, leaving little benefit to the host country.
} 
virtuous integration of developing countries in world trade flows. ${ }^{14}$ Despite this emphasis on North-South agreements, ECLAC (2013) and ESTEVADEORDAL, BLYDE and SUOMINEN (2013) argue that GVCs tend to be located regionally, especially around the North America, East Asia and Europe because of trade costs (transport and logistics) and of preferential policies of trade. In other words, trade agreements have not been the only factor that stimulate the formation of the regional chains; otherwise, Africa and Latin America would have a greater insertion in those chains.

Although the contemporary literature about productive fragmentation date from the 80s, the concept is not new. We can find its origins in the ECLAC analysis and reflections about the development of Latin America. This approach associates the productive integration to a broader process of industrialization and development, conceiving integration as an instrument to advance in that process. Productive and economic integration would support industrialization insofar as it generates a regional market that would permit small economies to gain scale. It also enable efficiency gains through the competition between regional firms, stimulating learning processes that permit those countries to subsequently export to developed countries. In other words, it would be an intermediate stage of the development of the domestic industry, supported by a temporary protection ${ }^{15}$. In this perspective, regional integration might be articulated to a mutual protection of domestic industries. The results of this process would be the acceleration of the economic growth of the region, the expansion and diversification of exports and the advance of the industrialization (TAVARES \& GOMES, 1998). The relevance of the external market constitutes an important element of the strategy of industrialization proposed by ECLAC which, according to OCAMPO (2001), combined an import substitution focus with the promotion of new industrial exports. In this sense, ECLAC recognized that the process of industrialization extended its effects when implemented in an economically integrated region.

After unsuccessful previous attempts to construct a institutional apparatus to regional integration, in 1980, "convinced that integration is one of the main means for Latin American countries to increase their economic and social development process and to ensure a better standard of living for their people"(LAIA, 1980, p.1), the countries of South America and Mexico established through the Treaty of Montevideo II, the Latin American Association for Integration (LAIA). It is within this institutional framework that the economic relationship between the countries of the region has been deepening in recent years. In 1980, the participation of LAIA in trade flows in the region was 13\%. In 2013 the participation of LAIA is 16\%, reaching $17 \%$ in 1997 . With regard to preferential margins, there has been a reduction of an average of $8 \%$ in the average tariff practiced in the region in relation to average tariff applied to Most Favored Nations.

LAIA emerged with the aim to eliminate gradually the barriers to regional trade, strengthening national economies and rationalizing production and foreign trade (SOUZA, 2003). In addition to the growth of trade, during the 1960s the hypothesis was that productive integration would also be able to generate an increase in the volume of foreign direct investment to the region. As a result, the productive structures would become more transnational. However, the adverse international scenario of the 70s has made the integration process to stagnate. The integrationist ideas remained in the background during the 80s due to the priority given to macroeconomic stability and fiscal adjustment.

Already in the 90s emerged a new integrationist paradigm in the region. This period was marked by the beginning of the process of globalization and by the revolution in information technologies, which reduced transportation costs and favored the consolidation of transnational companies. The new international scenario led Latin American countries to rethink their development policies. According to DI FILIPPO (1998), the economic crisis and the subsequent rescheduling of debits of Latin American countries in the 80s, as well as the perception that the ECLAC development model faced strong limits resulted in a change of the integration paradigm in the region. In this context, ECLAC proposes a new development strategy for the

\footnotetext{
14 This perspective restricts the potential benefits of South-South agreements, favoring the opening of developing countries to the trade with developed countries.

15 This strategy could be seen as a necessary stage for the creation of more efficient industries and to reduce external vulnerability, which would enable Latin America to become more competitive, permitting a better insertion in the international market.
} 
region, called "productive change with equity"16. Regional integration now reappears in the form of an open regionalism, which proposes that an open integration is able to create trade between countries in a context of multilateral liberalization, minimizing trade diversion and reducing transaction costs caused by trade regulations, thus increasing the competitiveness of the exports (DI FILIPPO, 1998 SELA, 2014).

The open regionalism could be seem as an effective mean to increase multilateralism in trade relations. The evolution of regionalism in the 90 s was marked on the one hand by the increase of intra-regional trade, and, on the other hand, by the proliferation of sub-regional agreements, such as Mercosur, as well as by the deepening of the existing ones.

The discussion about how to integrate appears under the implementation of the Mercosur agreement, contrasting two different perspectives: the "commercialist" and the "industrialist". CHUDNOVSKY and CAMPBELL (1991) argue that in the "commercialist" vision the productive integration appears directly as a result of a process of trade liberalization, leading to an intersectoral specialization based on static comparative advantages. The government's role would be restricted to the promotion of trade liberalization, without direct influence on allocative decisions. According to CASTILHO (2012), the policies based on this perspective tend to be focused only in trade and macroeconomic aspects, giving special importance to the management of the exchange rates. Contrasting to this perspective, in the "industrialist" view, the integration should be wide, constituting a mechanism to strengthen the regional industry affected by the competition from the rest of the world. The government would perform an active role that tries to monitor the productive activity in order to facilitate the further development of the industrial development process. Unlike the "commercialist" view, the intrasectoral productive specialization would more relevant, being based on dynamic comparative advantages (CHUDNOVSKY and CAMPBELL, 1991).

Despite the benefits generated by preferential trade agreements to the productive integration, SELA (2014) concludes that the open regionalism has not achieved its initial objectives. The economic, technological and social gap between different countries in the region wasn't reduced. On the contrary, the least developed countries have accumulated growing deficits with more developed partners.

\section{The evolution of the automotive industry in Latin America}

Since the 1950s, the automobile sector in Latin America was one of the main targets of a strategy of industrialization through import substitution and had a high degree of protectionism. However, the sector has always been heavily dominated by foreign companies, and the installation of assembly plants in LAIA countries - especially in Brazil, Mexico and Argentina - was part of the strategy of large transnational corporations (especially European and North American). Initially, the industries aimed to focus on the domestic demand of these countries with low relationship with external markets. Investments in modernization and technology were limited so the automotive sector in the region has accumulated a technological gap with respect to developed economies until the late 80's (ECLAC, 2009 and BORGES, 2011).

In the '90s, induced by the liberalizing reforms, Latin American industries have undergone a productive modernization and automakers from the major countries of the region (Argentina, Brazil and Mexico) began to produce not only for their domestic markets but also to export to other countries in the region. In this context, the automotive industry has become an important element in the international

\footnotetext{
16 The regional integration policy adopted in Latin America in this decade would be based in a more liberal perspective comprising a wider process including different topics (trade in services, investment, etc.). Commercial blocks should create an intense trade between their signatories without increasing the barriers for other countries and without generating processes of the trade deviation. The open regionalism would permit a regional integration founded in an international economy more open and transparent (ECLAC, 2001). In this perspective, regional integration would be able to generate economic benefits, such as an increasing production efficiency, innovation and diffusion of relevant technologies among the region, providing an improvement in the expectations of agents and an increase in FDI flows. It represents an essential step towards a broader international integration, through which the countries seek to transform their industries in order to make them more efficient (BRAGA, 2001; SELA, 2014).
} 
integration strategy, being supported by preferential trade agreements like NAFTA ${ }^{17}$ (North American Free Trade Agreement), in the case of Mexico and the MERCOSUR ${ }^{18}$ (Common Market of the South) in the case of Brazil and Argentina. Trade agreements, carried out through bilateral agreements under LAIA, acted to deepen productive complementarities between countries and as a way to overcome the limitations of domestic markets (HUMPHREY and MEMEDOVIC, 2003).

Even today, the regional distribution of automotive production in the region shows a similar pattern. ECLAC (2009) identifies three important regions within the LAIA for the automotive market. The first comprises Mexico, but with a production targeted for the NAFTA market. The second region is the Mercosur, specifically Brazil and Argentina. Finally, a third region includes the Andean Community (Colombia, Ecuador and Venezuela). But according to the study, the main producers are still Brazil and Mexico, which together account for $90 \%$ of total vehicle production in Latin America ${ }^{19}$.

Data about vehicle production in LAIA ${ }^{20}$ indicate that, between 2001 and 2012, the most important producing countries in the region are Brazil and Mexico (Figure 1). Brazil accounts for 51\% on average of the LAIA vehicle production, and its production has nearly doubled over this period, despite the small decline in 2009. The Mexico average share in the production of vehicles is $38 \%$ and the increase in the volume produced is also very significant. Although the downturn caused by the crisis in 2009 has been the most pronounced in the region, Mexico had a good recovery in the following year. Argentina is the third largest producer, accounting for an average of $8 \%$ of the total production of vehicles in LAIA. For other countries, the participation and the produced volume is very small.

Following the trend observed in the production, Brazil and Mexico are the largest car sellers in the region. The Brazilian participation has been increasing over the seven years analyzed: its share in the vehicles sold by the LAIA countries reached $44 \%$ in 2005 and was expanded to 56\% in $2012^{21}$. Mexico already shows an opposite trend, accounting for 29\% of the sales in 2005, but dropping to 15\%. in 2012 . The same happened with Venezuela, which in 2005 accounted for $4 \%$ of the sales, but currently represents only $2 \%$ of LAIA sales. Argentina is the third largest seller, accounting for $12 \%$ of the sales in 2012. Chile and Colombia have a share close to 5\%. Other countries have negligible shares.

Figure 1: Evolution of vehicle production in LAIA selected countries (in thousands)

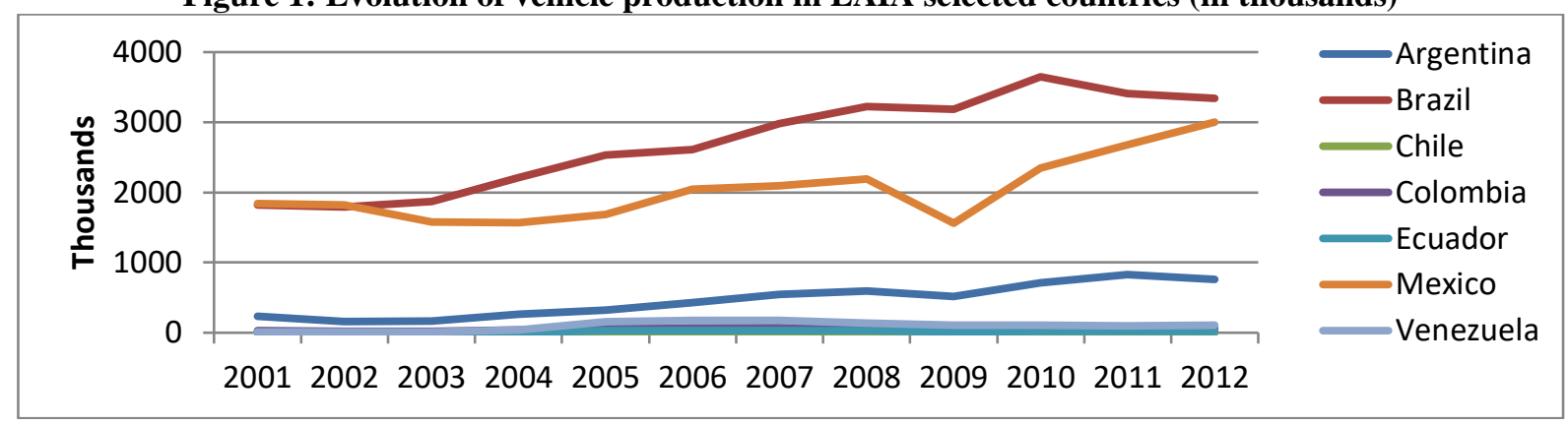

Source: Own elaboration based on data from OICA.

Concerning international trade flows (Table 1), the main exporter of LAIA is Mexico, which, despite losing importance in the period between 2000 and 2011, still accounted for about 77\% of exports from LAIA in 2012-2013. The second largest exporter is Brazil (14.3\% in 2012-2013), followed by Argentina (6.7\%).

\footnotetext{
${ }^{17}$ In the case of NAFTA, the agreements comprised the trade between Mexico and the United States. Despite being a member of LAIA and have agreements in the automotive sector with Mercosur, Mexico most important partner is the United States.

${ }_{18}$ Even before the Mercosur, Brazil and Argentina signed the Economic Complementation Agreement in 1990,, in order to stimulate the automotive sector through the implementation of zero tariff for these products.

${ }^{19}$ These markets have been specialized in different types of cars: Brazil produces mostly small cars to Mercosur market, while Mexico focus on medium and large cars to the American market.

${ }^{20}$ The presentation of data about LAIA production will be limited to the countries available on the OICA database, which are Argentina, Brazil, Chile, Colombia, Ecuador, Mexico and Venezuela.

${ }^{21}$ This percentage reached $61 \%$ of sales in 2009 .
} 
Imports have a more diversified profile, although Mexico is the main importer (45.8\% in 2012-2013), followed by Brazil (23.6\%) and Argentina (14.4\%).

Table 1: Share of each ALADI country in regional vehicles exports and imports (\% of total)

\begin{tabular}{|c|c|c|c|c|c|c|c|c|c|c|}
\hline \multirow[t]{2}{*}{ Countries } & \multicolumn{2}{|c|}{$2000-2002$} & \multicolumn{2}{|c|}{ 2003-2005 } & \multicolumn{2}{|c|}{$2006-2008$} & \multicolumn{2}{|c|}{$2009-2011$} & \multicolumn{2}{|c|}{ 2012-2013 } \\
\hline & EXP & IMP & EXP & IMP & EXP & IMP & EXP & IMP & EXP & IMP \\
\hline Argentina & 3.6 & 5.8 & 3.6 & 7.6 & 6 & 12.1 & 8.2 & 14.2 & 6.7 & 14.4 \\
\hline Bolivia & 0 & 0.2 & 0 & 0.3 & 0 & 0.5 & - & - & 0 & 0.6 \\
\hline Brasil & 12.9 & 12 & 19.8 & 11.9 & 20.2 & 16.9 & 17.4 & 24.6 & 14.3 & 23.6 \\
\hline Chile & 0.3 & 2.8 & 0.5 & 4.9 & 1 & 5.5 & 1 & 6.1 & 0.9 & 5.9 \\
\hline Colômbia & 0.7 & 2.3 & 0.8 & 2.8 & 1.3 & 3.7 & 0.3 & 3.9 & 0.8 & 3.6 \\
\hline Equador & 0.2 & 1.2 & 0.1 & 1.8 & 0.2 & 1.7 & 0.3 & 2 & 0.2 & 1.6 \\
\hline Mexico & 81.6 & 68.9 & 74.5 & 65 & 71 & 51.4 & 72.4 & 43.7 & 77 & 45.8 \\
\hline Paraguai & 0 & 0.4 & 0 & 0.4 & 0 & 0.8 & 0 & 1 & 0 & 0.9 \\
\hline Peru & 0 & 1.2 & 0 & 1.2 & 0 & 1.7 & 0 & 2.4 & 0 & 2.9 \\
\hline Uruguai & 0.2 & 0.6 & 0.1 & 0.4 & 0.2 & 0.6 & 0.2 & 0.8 & 0.2 & 0.8 \\
\hline Venezuela & 0.5 & 4.7 & 0.6 & 3.9 & 0.1 & 5.1 & 0.1 & 1.4 & 0 & 0 \\
\hline LAIA (in \%) & 100 & 100 & 100 & 100 & 100 & 100 & 100 & 100 & 100 & 100 \\
\hline LAIA (US\$ million) & 39473 & 31402 & 44337 & 35482 & 62008 & 58903 & 65452 & 70747 & 89705 & 94217 \\
\hline
\end{tabular}

Table 2 illustrates LAIA share in total exports and imports of its members. The profile of intraregional trade - both in terms of destination as the origin - differs substantially from that of extra-regional trade. For Mexico, which is the largest exporter in the region, LAIA has less importance than other countries, accounting for only $6.8 \%$ of its exports and 3.4\% of its imports. For Brazil, exports from LAIA correspond to $78.4 \%$ of total exports and $36.9 \%$ of total imports. For Argentina, which is the third largest exporter in the region, the LAIA absorbs $94 \%$ of its exports and provides $62.8 \%$ of its imports, with much of that trade being conducted with Brazil. For other countries, despite the limited size of the industry, the regional trade is responsible for almost all of its exports (except in the case of Peru) and to a smaller proportion of its imports, which generally come from other regions.

Table 2: LAIA share in each member country exports (in \%)

\begin{tabular}{lcccccccccc}
\hline Countries & \multicolumn{2}{c}{$\mathbf{2 0 0 0}-\mathbf{2 0 0 2}$} & \multicolumn{2}{c}{$\mathbf{2 0 0 3}-\mathbf{2 0 0 5}$} & \multicolumn{2}{c}{$\mathbf{2 0 0 6}-\mathbf{2 0 0 8}$} & \multicolumn{2}{c}{$\mathbf{2 0 0 9 - 2 0 1 1}$} & \multicolumn{2}{c}{$\mathbf{2 0 1 2 - 2 0 1 3}$} \\
& EXP & IMP & EXP & IMP & EXP & IMP & EXP & IMP & EXP & IMP \\
\hline Argentina & 84.5 & 45.4 & 77.0 & 61.7 & 84.7 & 62.4 & 94.1 & 68.2 & 94.0 & 62.8 \\
Bolivia & 32.5 & 9.9 & 32.9 & 14.6 & 32.1 & 5.9 & - & - & 100.0 & 12.8 \\
Brasil & 46.4 & 29.6 & 49.7 & 20.3 & 59.0 & 32.9 & 73.3 & 36.6 & 78.4 & 36.9 \\
Chile & 82.3 & 19.2 & 88.2 & 21.1 & 89.6 & 13.3 & 90.2 & 9.2 & 92.1 & 7.0 \\
Colômbia & 92.1 & 18.2 & 91.5 & 24.6 & 92.1 & 19.2 & 74.1 & 23.6 & 89.1 & 31.0 \\
Equador & 99.2 & 37.4 & 95.3 & 44.4 & 98.7 & 30.6 & 97.9 & 18.5 & 93.5 & 20.0 \\
Mexico & 0.8 & 5.1 & 1.0 & 9.5 & 3.8 & 7.4 & 6.8 & 4.5 & 6.8 & 3.4 \\
Paraguai & 63.6 & 22.6 & 65.6 & 23.1 & 72.3 & 18.4 & 80.9 & 16.1 & 96.9 & 15.8 \\
Peru & 30.9 & 7.9 & 39.3 & 13.4 & 45.8 & 14.6 & 57.5 & 12.7 & 49.8 & 12.9 \\
Uruguai & 98.6 & 39.6 & 92.8 & 57.9 & 91.5 & 53.4 & 97.0 & 47.7 & 98.0 & 37.8 \\
Venezuela & 30.4 & 30.4 & 44.0 & 37.6 & 59.2 & 38.5 & 33.2 & 32.7 & - & - \\
\hline LAIA & $\mathbf{1 1 . 1}$ & $\mathbf{1 3 . 0}$ & $\mathbf{1 5 . 0}$ & $\mathbf{1 7 . 7}$ & $\mathbf{2 2 . 2}$ & $\mathbf{2 1 . 6}$ & $\mathbf{2 7 . 1}$ & $\mathbf{2 3 . 9}$ & $\mathbf{2 4 . 6}$ & $\mathbf{2 2 . 0}$ \\
\hline
\end{tabular}

Source: Own elaboration based on data from COMTRADE.

\section{The institutional dimension of automotive production integration in LAIA: trade agreements,} tariff preferences and other policies for the sector

Since 1990, through the signing of an Economic Complementation Agreement, Brazil and Argentina have tried to increase the productive integration in the auto industry. Even in the 90s and prior to the Mercosur agreement, Brazil and Argentina have implemented a set of incentives (defined as "automotive regimes") to stimulate the automotive sector. In Argentina, the automotive regime was established in March 1991 and was broader than the Brazilian. As a result, there was a rapid fall in car prices and an increase in 
the production capacity above demand by the year $1994^{22}$. Among the measures, the most important was the coefficients that set limits on imports of manufacturers according to their exports, domestic production and investments in local factories. The Brazilian policies, dating from the 80s, although less incisive, included changes in tax structure and incentive programs for exports. But only with the reductions of trade barriers in the 90s, the impact on the sector was more effective. Despite previous policies, the Brazilian automotive regime was only installed in 1994 and was focused on incentives to domestic demand, stimulating the replacement of auto imports for local consumption. (CASOTTI and GOLDENSTEIN, 2008 and BORGES, $2011)^{23}$.

The relationship between the two countries was strengthened with the signing of Mercosur Agreement in 1995. Since then, the production planning assumed a regional character, with the creation of more integrated, competitive and specialized industrial parks ${ }^{24}$. But the Mercosur agreement itself does not set a common automotive policy. The sector continued to be governed by autonomous automotive regimes of each country. In the Brazilian regime, the raw materials from other Mercosur partners would receive the same treatment of the national product and the domestic content was equalized with Argentina in 60\% (CASOTTI and GOLDENSTEIN, 2008 and BORGES, 2011). The rationalization of the production among Mercosur auto firms follows a pattern based on the reduction of the number of models produced in each plant, in order to generate economies of scale and specialization gains. The subsidiaries of automakers divide the production of models and of versions of the same model between Brazil and Argentina in order to capture those gains. At the same time, we observe changes in the auto parts sector, following international trends based on the search of production flexibility, scale and diversification, with the consolidation of regional supply chains.

Only with the close expiration of the Brazilian and Argentine automotive regimes, which would end in 1999, began the development of a Automotive Policy in Mercosur. This new policy would seek to extinguish the tariff barriers in the region, as well as the offsetting criteria, eliminating unilateral incentives that would cause distortions in competitiveness and setting a common external tariff by $20 \%$. Thus, the main objective was the formation of an integrated regional platform to export to other markets. However, this policy had proved difficult to be implemented and the bilateral agreements defined under LAIA Agreement continued to be more relevant. Trade between Brazil and Argentina was coordinated by protocols and export deviation coefficients previously determined. This agreement extinguished the tariffs for automotive products between the countries and the bilateral trade came to be balanced by import quotas ${ }^{25}$. The 38th Additional Protocol of the Economic Complementation Agreement No. 14 intended to promote a productive specialization and a complementation between automotive industries in Brazil and Argentina ${ }^{26}$. The production of the other members is carried out mainly through CKD regimes ${ }^{27}$, being highly dependent on imports, mostly from the major partners (CASOTTI and GOLDENSTEIN, 2008 and BORGES, 2011).

But, even considering that Mercosur does not have a common policy for the automotive sector, its members have established partial scope agreements with other members of LAIA. Since 2006 there is an

\footnotetext{
${ }^{22}$ Part of this success can be attributed to the exchange rate policy of parity with the dollar adopted by Argentina, which has kept inflation under control.

${ }^{23}$ Among those measures, the main one was the reduction of import taxes by $90 \%$ for capital goods, $85 \%$ for intermediate goods and $50 \%$ for finished vehicles. Also noteworthy is the reduction of the period of depreciation of vehicles for business uses.

${ }^{24}$ BORGES (2011) points out that, on the other hand, the auto parts sector remained very fragile in the region. Auto parts companies are usually national, being little integrated into the global market and with low bargaining power in the supply chain.

${ }^{25}$ The trade between Brazil and Argentina is still governed by criteria related to deviation ratio on exports. Through the 38th Additional Protocol of the Economic Complementation Agreement No. 14 it was decided that, until 2013, in the case of a trade deficit for Argentina, the coefficient should not exceed 1.95; conversely, in the case of a trade deficit for Brazil, the coefficient should not exceed 2.5. But because of the economic crisis in Argentina, the agreement has not been renegotiated and these parameters were maintained for years to come.

${ }^{26}$ This program would be implemented through the support of BNDES (the Brazilian development Bank) financing, with the intend to promote the international integration of the region, through increased exports, development of local auto parts, incorporation of new technologies and qualification of human resources, with special emphasis on the auto parts industry.

${ }^{27}$ The CKD (Completely Knock-Down) regime consists of a set of auto pieces produced by the matrix and sent in a kit format for countries in which the automakers are located. The CKD kits are treated in the literature as "dismantled cars".
} 
agreement between the members of Mercosur and Chile, through which automotive products from Mercosur with local content superior to 60\% are exempt from import duties to access the Chilean market (ACE no 35). Mercosur also established a free trade agreement for light vehicles with Mexico (ACE no. 55). Brazil and Uruguay also signed an agreement providing that Uruguay can export tax-free vehicles to Brazil, since they contain a minimum Mercosur origin index of 60\% (CASOTTI and GOLDENSTEIN, 2008).

The Andean countries have similar production structures and with some degree of complementarity. As with the smaller Mercosur members, they have small manufacturers operating under the CKD regime. Most of these kits are provided by the big producers operating in Brazil and Argentina. However, with the significant growth of Asian countries in recent years, the Andean production is losing importance. Colombia, Ecuador and Venezuela have their domestic markets attended by imports. Chile (which have not entered in any of the commercial blocks mentioned above) has a high degree of trade openness and a range of bilateral preferential agreement with other countries of LAIA, with the automobile industry being composed by automakers oriented mainly to the external market (CASOTTI and GOLDENSTEIN, 2008).

In Mexico, since the trade liberalization in 1985, the production of vehicles is strongly dependent on the US marked and this relationship has deepened after the creation of NAFTA in 1994. This dependency became Mexico extremely vulnerable to changes that occurred in US markets (STURGEON et al., 2009). According to ECLAC (2009) some factors contribute to make Mexico attractive to NAFTA, including low wage levels, geographical proximity and the large domestic market (both for new vehicles and for used). Even before the creation of NAFTA, Mexico was already receiving preferential access to the US market, being viewed as a major export platform for the region. Over the past two decades, Mexico has also expanded the value added to the production of vehicles, investing in skilled labor and incorporating innovations to the models produced in the country. Especially after the 2008 crisis, the country has also invested in the production of compact cars to meet new demands.

\subsection{Analysis of tariff structure of the region}

A key element of the trade policy adopted by LAIA refers to the concession of tariff preferences to their members, especially through partial agreements. "Partial Scope Agreements" are those in which some members participate and are used to deepen the process of regional integration through a progressive multilateralization (LAIA, 1980). Some of these agreements seek to reinforce the complementarities of production systems in the region. Most of them comprise the automotive sector, being implemented in the absence of a comprehensive agreement that focused on an effective productive integration of all members of the Association.

Through a comparative analysis between tariffs applied to $\mathrm{MFN}^{28}$ and preferential tariffs applied by ALADI member countries for intermediate goods in the automotive industry in 2010, we can observe that the sector has undergone an effective process of tariff reduction among the members of the Association (see Table 3). The most practiced MFN rate reached approximately 17\%, being imposed by Argentina and Brazil, while the lowest rates were imposed by Mexico (3.3\%) and Peru (2.6\%). The preferential rate varied between 1.4\% (Chile and Peru) and 7.7\% (Venezuela). We found that the average tariff applied to the Association partners was systematically lower than that applied to other partners (MFN tariff). The most significant discounts were held by Uruguay (87\%), Brazil (86\%), Argentina (84\%), Chile (77\%) and Paraguay (70\%), while the fewer were held by Ecuador (30\%), Bolivia (38\%), Venezuela (40\%) and Peru (45\%).

\footnotetext{
${ }^{28}$ Data about tariff structure was extracted from the TRAINS database for the year 2010. Tariff data were extracted at full breakdown (6 digits) and re-aggregated using the same product classification applied to trade data.
} 
Table 3: Tariffs for intermediate goods applied by ALADI countries to their Association and MFN partners in the automotive industry in 2010 (\%).

\begin{tabular}{|c|c|c|c|c|c|c|c|c|c|c|c|c|c|}
\hline \multirow[b]{2}{*}{ Countries } & \multicolumn{13}{|c|}{ Trade Partners } \\
\hline & MFN & ALADI & Argentina & Bolivia & Brazil & Chile & Colombia & Ecuador & México & Paraguay & Peru & Uruguay & Venezuela \\
\hline Argentina & 17.2 & 2.7 & - & 0.7 & 0.0 & 0.0 & 4.0 & 4.1 & 6.0 & 4.7 & 3.6 & 0.0 & 4.1 \\
\hline Bolivia & 10.2 & 6.4 & 4.1 & - & 4.1 & 9.6 & 9.7 & 9.4 & 0.0 & 3.4 & 9.7 & 3.9 & 9.7 \\
\hline Brazil & 17.4 & 2.4 & 0.0 & 0.8 & - & 0.0 & 3.9 & 5.4 & 3.0 & 4.6 & 3.1 & 0.0 & 3.2 \\
\hline Chile & 6.0 & 1.4 & 3.7 & 0.0 & 3.7 & - & 0.0 & 0.4 & 0.0 & 2.8 & 0.0 & 3.4 & 0.0 \\
\hline Colombia & 11.9 & 5.5 & 4.6 & 8.9 & 4.2 & 0.0 & - & 9.4 & 0.4 & 3.9 & 10.1 & 3.9 & 10.1 \\
\hline Ecuador & 8.3 & 5.8 & 5.1 & 8.1 & 4.6 & 1.3 & 8.2 & - & 8.3 & 4.1 & 8.2 & 2.2 & 8.2 \\
\hline México & 3.3 & 1.5 & 2.0 & 0.0 & 1.3 & 0.0 & 0.0 & 2.8 & - & 2.7 & 3.0 & 0.0 & 3.0 \\
\hline Paraguay & 10.3 & 3.1 & 1.8 & 0.5 & 2.7 & 0.1 & 4.7 & 2.6 & 9.1 & - & 2.6 & 2.6 & 4.3 \\
\hline Peru & 2.6 & 1.4 & 1.0 & 2.2 & 1.0 & 0.0 & 2.3 & 2.2 & 2.4 & 0.6 & - & 0.1 & 2.3 \\
\hline Uruguay & 14.5 & 1.9 & 0.3 & 0.9 & 0.3 & 0.3 & 4.3 & 2.4 & 0.3 & 3.4 & 1.6 & - & 5.5 \\
\hline Venezuela & 12.9 & 7.7 & 4.1 & 11.6 & 4.0 & 0.0 & 12.1 & 11.8 & 12.4 & 4.2 & 12.1 & 4.9 & - \\
\hline
\end{tabular}

Source: Own elaboration based on data from TRAINS.

The tariffs applied to final goods of the automobile industry were relatively higher than those applied to intermediate goods (Table 4). The most applied MFN tariff was 28.6\% (Colombia) and the lowest was 6\% (Chile). Preferred rates are also generally higher, ranging from 1.8\% (Chile) to 20.9\% (Venezuela). Similarly to intermediate goods, the countries that implemented the highest tariff discounts were the Mercosur countries: Brazil (86\%), Uruguay (84\%), Argentina (80\%) and Paraguay (75\%). On the other hand, smaller concessions were granted by Bolivia (22\%), Venezuela (23\%), Peru (24\%) and Ecuador (34\%). Colombia and Venezuela are the countries with the highest rates. In Venezuela the rate is above 13\% for all partners. Peru is the country that practices the more homogeneous rates, around $8 \%$ for seven of the ten partners. Argentina and Brazil, as well as in the case of intermediate goods, apply zero tariff for bilateral cars imports and to those that comes from Chile and Uruguay. The country with the lowest rates is Chile, reflecting the numerous preferential agreements negotiated with the countries of Mercosur and the Andean Community

Table 4: Tariffs for final goods applied by ALADI countries to their Association and MFN partners in the automotive industry in 2010).

\begin{tabular}{|c|c|c|c|c|c|c|c|c|c|c|c|c|c|}
\hline \multirow[b]{2}{*}{ Countries } & \multicolumn{13}{|c|}{ Trade partners } \\
\hline & MFN & ALADI & Argentina & Bolivia & Brazil & Chile & Colombia & Ecuador & México & Paraguay & Peru & Uruguay & Venezuela \\
\hline Argentina & 22.1 & 4.4 & - & 1.0 & 0.0 & 0.0 & 6.5 & 5.6 & 17.1 & 2.6 & 4.4 & 0.0 & 6.5 \\
\hline Bolivia & 10.0 & 7.8 & 9.2 & - & 9.2 & 8.6 & 8.8 & 8.0 & 0.0 & 7.6 & 8.8 & 8.8 & 8.8 \\
\hline Brazil & 22.1 & 3.8 & 0.0 & 1.0 & - & 0.0 & 9.0 & 6.9 & 2.3 & 5.0 & 4.4 & 0.0 & 9.0 \\
\hline Chile & 6.0 & 1.8 & 5.3 & 0.0 & 5.3 & - & 0.0 & 0.0 & 0.0 & 0.6 & 0.5 & 4.8 & 2.1 \\
\hline Colombia & 28.6 & 14.4 & 14.6 & 19.1 & 14.6 & 0.6 & - & 20.7 & 0.6 & 13.7 & 23.0 & 14.4 & 23.0 \\
\hline Ecuador & 16.3 & 10.7 & 7.1 & 15.7 & 7.1 & 0.0 & 16.0 & - & 16.1 & 6.2 & 16.0 & 6.6 & 16.0 \\
\hline México & 18.3 & 8.3 & 6.3 & 0.3 & 2.4 & 0.3 & 0.3 & 18.3 & - & 18.3 & 18.3 & 0.3 & 18.3 \\
\hline Paraguay & 19.0 & 4.8 & 2.0 & 0.4 & 2.0 & 0.0 & 7.4 & 3.6 & 18.5 & - & 4.7 & 1.9 & 7.4 \\
\hline Peru & 9.0 & 6.8 & 7.7 & 7.7 & 7.7 & 0.7 & 8.1 & 7.7 & 8.5 & 7.0 & - & 5.4 & 8.1 \\
\hline Uruguay & 20.4 & 3.2 & 0.0 & 0.7 & 0.0 & 0.0 & 9.7 & 7.2 & 0.0 & 2.2 & 4.0 & - & 8.7 \\
\hline Venezuela & 27.1 & 20.9 & 14.8 & 27.1 & 14.8 & 16.1 & 27.1 & 27.1 & 27.1 & 13.4 & 27.1 & 14.4 & - \\
\hline
\end{tabular}

Source: Own elaboration based on data from TRAINS.

Disaggregated bilateral tariffs show that LAIA countries grant significant tariff reductions to its association partners. The countries with the highest relative level of economic development apply the highest discount margins. We can also stress the existence of bilateral agreements, the most relevant being the Agreement about a Common Automotive Policy established between Brazil and Argentina, comprising trade stimulus in order to provide a productive integration between the partners. However, there are other important agreements for the sector which extend the list of products subject to tariff reduction or exemption. Among these agreements, we can highlight: the ECA No.35 that establishes tariff preferences for the automotive trade between the Mercosur countries and Chile, as well as the ECA No. 55 that establishes the tariff exemption for Brazilian and Uruguayan imports from Mexico. Obviously, these preferences are granted subject to certain conditions: in almost all agreements there are clauses about rules of origin (mostly 
requiring $60 \%$ local content for the product to receive the tariff benefits). In some agreements, there are also criteria to "balance" trade between the members, like the trade diversion rate established between Brazil and Argentina (ECA No.14).

\section{Productive Integration in LAIA automotive industry: empirical evidences}

Once characterized the importance of LAIA, we analyze the evolution of intra-industry trade in each country, with its regional partners and with extra-regional partners, by calculating the Grubel-Lloyd index (Table 5). ${ }^{29}$ As this index is based on the overlap of exports and imports in the same industry, it can give a first insight of the productive articulation among countries. We observe that countries with higher levels of intra-industry trade in intra-LAIA trade are Brazil (0.67 in 2010), Ecuador (0.57), Argentina (0.56) and Uruguay (0.46). On the other hand, Colombia and Venezuela showed a significant decrease in the degree of intra-industry trade with its association partners. In the extra-LAIA trade, we observed a significant reduction of intra-industry trade to Argentina and Brazil, in contrast to the significant increase to Mexico. These data suggest that while Brazil and Argentina have the regional market as key partners for their automotive products, Mexico is more directed to the extra-regional trade.

Table 5: Grubel-Lloyd Index to LAIA members in 2000 and 2010

\begin{tabular}{|c|c|c|c|c|}
\hline & \multicolumn{2}{|c|}{ Intra-LAIA } & \multicolumn{2}{|c|}{ Extra-LAIA } \\
\hline & 2000 & 2010 & 2000 & 2010 \\
\hline Argentina & 0.58 & 0.56 & 0.23 & 0.16 \\
\hline Bolívia & 0.04 & 0.10 & 0.02 & 0.00 \\
\hline Brasil & 0.59 & 0.67 & 0.56 & 0.33 \\
\hline Chile & 0.30 & 0.24 & 0.04 & 0.03 \\
\hline Colômbia & 0.61 & 0.30 & 0.04 & 0.04 \\
\hline Equador & 0.37 & 0.57 & 0.00 & 0.01 \\
\hline Mexico & 0.28 & 0.36 & 0.49 & 0.64 \\
\hline Paraguai & 0.01 & 0.00 & 0.00 & 0.00 \\
\hline Peru & 0.06 & 0.06 & 0.02 & 0.01 \\
\hline Uruguai & 0.47 & 0.46 & 0.01 & 0.04 \\
\hline Venezuela & 0.28 & 0.05 & 0.16 & 0.09 \\
\hline LAIA & 1.00 & 1.00 & 0.56 & 0.70 \\
\hline
\end{tabular}

The Grubel-Lloyd index calculated for bilateral trade reveals the pattern of integration in automotive production between LAIA partners (Table 6). Argentina has a high degree of productive integration with Chile (0.70) and Brazil (0.58) and to a lesser extent to Uruguay (0.31). Brazil, besides the already mentioned integration to Argentina, has also an intense exchange of goods with Mexico (0.46) and Uruguay (0.51). Ecuador and Colombia also have a high degree of intra-industry trade (0.53) as well as, to a lesser extent, Bolivia and Chile (0.28) and Peru and Chile (0.19).

\footnotetext{
29 The Grubel-Lloyd Index is defined by, $B=\frac{(X+M)-(X-M)}{(X+M)}$ where $X$ corresponds to exports and $M$ to imports. The closer from 1 is the index, the greater will be the intra-industry trade.
} 
Table 6: Bilateral intra-industry trade of LAIA members in 2010 (Grubel-Lloyd index)

\begin{tabular}{lrrrrrrrrrrrr}
\hline Countries & LAIA & Argentina & Bolivia & Brazil & Chile & Colombia & Ecuador & Mexico & Paraguay & Peru & Uruguay & Venezuela \\
\hline Argentina & 0.56 & - & - & 0.58 & 0.70 & 0.01 & 0.00 & 0.08 & - & 0.00 & 0.31 & 0.00 \\
Bolivia & 0.10 & - & - & 0.00 & 0.28 & 0.00 & - & 0.00 & - & - & - & 0.00 \\
Brazil & 0.67 & 0.58 & 0.00 & - & 0.05 & 0.01 & 0.00 & 0.46 & 0.00 & 0.00 & 0.51 & 0.07 \\
Chile & 0.24 & 0.70 & 0.28 & 0.05 & - & 0.00 & 0.02 & 0.01 & 0.01 & 0.19 & 0.04 & 0.00 \\
Colombia & 0.30 & 0.01 & 0.00 & 0.01 & 0.00 & - & 0.53 & 0.03 & - & 0.03 & 0.04 & 0.02 \\
Ecuador & 0.57 & 0.00 & - & 0.00 & 0.02 & 0.53 & - & 0.04 & 0.05 & 0.02 & - & 0.00 \\
Mexico & 0.36 & 0.08 & 0.00 & 0.46 & 0.01 & 0.03 & 0.04 & - & - & 0.01 & 0.01 & 0.06 \\
Paraguay & 0.00 & - & - & 0.00 & 0.01 & - & 0.05 & - & - & - & 0.03 & - \\
Peru & 0.06 & 0.00 & - & 0.00 & 0.19 & 0.03 & 0.02 & 0.01 & - & - & - & 0.04 \\
Uruguay & 0.46 & 0.31 & - & 0.51 & 0.04 & 0.04 & - & 0.01 & 0.03 & - & - & 0.29 \\
Venezuela & 0.05 & 0.00 & 0.00 & 0.07 & 0.00 & 0.02 & 0.00 & 0.06 & - & 0.04 & 0.29 & - \\
\hline
\end{tabular}

Source: Own elaboration based on data from COMTRADE.

Data about exports and imports of intermediate and final goods in the automotive industry from the LAIA countries (Table 7 and Table 8) illustrate the pattern of regional productive integration. The largest exporter in the region is Mexico, which exported U\$\$ 69 billion in automotive goods in 2012-2013, with US\$ 38 billion of intermediate goods and US\$ 30 billion of final goods, which corresponded to $77 \%$ of total exports of LAIA. The Brazil, although in much lower proportion to Mexico, is the second largest exporter, especially of intermediate goods (US\$ 8 billion in 2012-2013). In contrast, Argentina - the third largest exporter - exported mainly final goods (US\$ 4 billion in 2012-2013). Exports of other members are significantly lower.

Table 7: LAIA automotive industry intermediate and final goods exports (US\$ 1.000)

\begin{tabular}{|c|c|c|c|c|c|c|c|c|c|c|}
\hline & \multicolumn{2}{|c|}{ 2000-2002 } & \multicolumn{2}{|c|}{ 2003-2005 } & \multicolumn{2}{|c|}{ 2006-2008 } & \multicolumn{2}{|c|}{ 2009-2011 } & \multicolumn{2}{|c|}{ 2012-2013 } \\
\hline & INTER & FINAL & INTER & FINAL & INTER & FINAL & INTER & FINAL & INTER & FINAL \\
\hline Argentina & 675,67 & 762,21 & 951,51 & 657,60 & $1.590,00$ & $2.147,17$ & $1.595,78$ & $3.799,26$ & $1.938,65$ & $4.042,01$ \\
\hline Bolivia & 1,68 & 0,85 & 1,54 & 0,91 & 0,96 & 1,37 & 1,63 & - & 3,96 & . \\
\hline Brazil & $3.100,46$ & $1.977,63$ & $5.086,84$ & $3.674,42$ & 7.589,73 & $4.971,65$ & $7.249,10$ & $4.156,41$ & $8.011,69$ & $4.816,92$ \\
\hline Chile & 57,72 & 53,77 & 106,16 & 114,14 & 190,27 & 426,51 & 272,42 & 372,62 & 329,07 & 467,75 \\
\hline Colombia & 75,98 & 182,56 & 88,89 & 253,82 & 226,50 & 560,54 & 195,23 & 4,41 & 223,82 & 480,01 \\
\hline Ecuador & 2,02 & 64,87 & 3,53 & 55,47 & 13,24 & 99,20 & 21,76 & 152,38 & 27,94 & 124,52 \\
\hline Mexico & $16.952,24$ & $15.255,42$ & $20.408,23$ & $12.604,45$ & $24.826,92$ & $19.216,70$ & $25.924,82$ & $21.492,97$ & $38.554,46$ & $30.476,68$ \\
\hline Paraguay & 0,19 & 0,03 & 0,13 & 0,03 & 0,35 & 0,25 & 0,88 & 0,27 & 21,43 & 0,43 \\
\hline Peru & 4,03 & 2,53 & 3,94 & 1,79 & 8,22 & 1,25 & 14,31 & 2,97 & 16,99 & 3,53 \\
\hline Uruguay & 20,11 & 67,52 & 37,50 & 2,29 & 87,41 & 5,64 & 104,01 & 54,10 & 80,47 & 84,61 \\
\hline Venezuela & 167,28 & 48,50 & 181,15 & 102,55 & 40,53 & 26,85 & 18,44 & 18,15 & - & 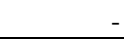 \\
\hline LAIA & $21.057,38$ & $18.415,89$ & $26.869,43$ & $17.467,49$ & $34.560,62$ & $27.447,27$ & $35.398,37$ & $30.053,54$ & $49.208,48$ & $40.496,47$ \\
\hline
\end{tabular}

The imports have similar profiles. Mexico is the main importer of the region, especially of parts and components: US\$ 34 billion in 2012-2013, corresponding to 59\% of LAIA imports of intermediate goods. Argentina and Brazil also have high levels of imports of intermediate goods, as well as Chile, which has expanding its automotive imports. Other countries import mostly final goods, but in much lower proportions. 
Table 8: LAIA automotive industry intermediate and final goods imports (US\$1.000)

\begin{tabular}{|c|c|c|c|c|c|c|c|c|c|c|}
\hline & \multicolumn{2}{|c|}{ 2000-2002 } & \multicolumn{2}{|c|}{ 2003-2005 } & \multicolumn{2}{|c|}{ 2006-2008 } & \multicolumn{2}{|c|}{ 2009-2011 } & \multicolumn{2}{|c|}{ 2012-2013 } \\
\hline & NTER & FINAL & INTER & FINAL & INTER & FINAL & NTER & FINAL & INTER & FINAL \\
\hline Arg & $1.244,87$ & 55,51 & $1.535,31$ & 150,39 & $3.912,65$ & $3.206,05$ & $5.415,54$ & $4.578,57$ & $6.738,36$ & $5.843,17$ \\
\hline Boli & & & & & & & & - & & \\
\hline Braz & $2.710,01$ & & & & & & & 4 & & \\
\hline Chile & 4 & & 5 & & & & & & & \\
\hline Colo & & & 53 & 6 & & & & & & \\
\hline & 77 & & & & & & & & & 868,84 \\
\hline Me & 348,56 & 3 & .242 & 5 & 21.015 & 9.2 & $4.330,88$ & $6.299,72$ & $34.580,45$ & $7.872,63$ \\
\hline Para & 35,09 & & & & 44 & & 274,88 & & & 553,62 \\
\hline Peru & 90 & 8 & 162 & 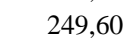 & & 9 & & 25 & 28 & $2.032,27$ \\
\hline & 110,73 & 62,94 & 69,17 & 56,63 & 163,27 & 165,62 & 247,28 & 341,76 & 219,05 & 458,67 \\
\hline & 379,64 & 106,30 & 2,61 & 980,62 & 922,81 & $2.102,75$ & 775,27 & 186,00 & - & \\
\hline LAIA & $1.755,77$ & $9.645,92$ & $23.290,48$ & $12.191,89$ & $35.006,65$ & $23.896,50$ & $43.063,85$ & $27.683,47$ & $57.374,57$ & $33.930,08$ \\
\hline
\end{tabular}

Source: Own elaboration based on data from COMTRADE.

In order to measure the degree of productive integration of LAIA members, we calculate the share of intermediate goods in total automotive industry trade for the period 2000 to 2013 (Table 9). Intra and extraLAIA trade are very distinct in this aspect. The LAIA countries, in most cases, export intermediate goods to their extra-regional partners. In the year 2012-2013, Argentina (98.6\%), Brazil (97.9\%) and Chile (97.4\%) basically export intermediate goods to countries outside LAIA, while Mexico has more diversified exports. In the intra-LAIA trade, the profile is quite different. Brazilian exports of automotive goods in the year 2012-2013 were composed of 52.7\% of intermediate goods, while in the case of Argentina and Mexico that share accounts for only $28.2 \%$ and $15.3 \%$, respectively. In aggregate, we observed a slight reduction in the share of intermediate goods in intraregional exports, which represented 42.7\% in the period 2000-2002 and was reduced to $36.9 \%$ in 2012-2013. The profile was different in the extra-regional trade, which expanded from $54.7 \%$ in $200-2002$ to $60.7 \%$ in $2012-2013$. These data suggest that exports of parts and components tend to be more significant for trade with third countries than with regional trade. Within LAIA, exports are still more intense in final goods for most of the partners.

Table 9: Share of the automotive industry intermediate goods exports in intra and extra-LAIA trade in (in \%)

\begin{tabular}{|c|c|c|c|c|c|c|c|c|c|c|}
\hline \multirow[t]{2}{*}{ Countries } & \multicolumn{2}{|c|}{$2000-2002$} & \multicolumn{2}{|c|}{ 2003-2005 } & \multicolumn{2}{|c|}{ 2006-2008 } & \multicolumn{2}{|c|}{ 2009-2011 } & \multicolumn{2}{|c|}{ 2012-2013 } \\
\hline & INTRA & EXTRA & INTRA & EXTRA & INTRA & EXTRA & INTRA & EXTRA & INTRA & EXTRA \\
\hline Argentina & 37.6 & 98.0 & 47.9 & 96.9 & 35.1 & 83.8 & 25.5 & 94.4 & 28.2 & 98.6 \\
\hline Bolivia & 82.3 & 58.7 & 66.9 & 60.9 & 84.3 & 44.0 & 100.0 & 100.0 & 100.0 & 100.0 \\
\hline Brazil & 48.4 & 72.0 & 39.1 & 76.8 & 49.8 & 75.7 & 57.3 & 80.7 & 52.7 & 97.9 \\
\hline Chile & 42.3 & 96.0 & 42.2 & 93.0 & 23.1 & 97.6 & 36.3 & 97.0 & 36.5 & 97.4 \\
\hline Colombia & 24.4 & 87.5 & 20.3 & 86.5 & 23.1 & 94.6 & 97.9 & 97.4 & 25.9 & 80.0 \\
\hline Ecuador & 2.6 & 56.0 & 3.3 & 60.1 & 10.7 & 88.4 & 10.7 & 99.1 & 12.7 & 99.6 \\
\hline Mexico & 51.8 & 52.6 & 54.1 & 61.9 & 16.6 & 57.9 & 12.6 & 57.8 & 15.3 & 58.8 \\
\hline Paraguay & 73.3 & 91.7 & 73.2 & 68.3 & 63.1 & 44.1 & 88.1 & 27.0 & 99.2 & 61.1 \\
\hline Peru & 63.9 & 60.3 & 77.2 & 63.2 & 88.0 & 85.7 & 82.8 & 82.8 & 73.7 & 91.8 \\
\hline Uruguay & 22.3 & 72.4 & 97.6 & 50.7 & 95.4 & 77.9 & 65.9 & 63.2 & 48.4 & 64.1 \\
\hline Venezuela & 27.9 & 99.2 & 19.5 & 98.7 & 35.2 & 96.3 & 94.9 & 28.3 & - & - \\
\hline LAIA & 42.7 & 54.7 & 40.4 & 64.2 & 39.9 & 60.2 & 39.4 & 59.5 & 36.9 & 60.7 \\
\hline
\end{tabular}

Source: Own elaboration based on data from COMTRADE. *World exports excluding LAIA

The profile of imports seems to be more diverse (Table 10). The largest economies of the regions are also the largest importers of intermediate goods in the extra-regional trade: in 2012-2013 imports from Mexico, Brazil and Argentina were composed of 81.3\%, 77,0\% and 65.1\%, respectively, of intermediate goods. But while Argentina and Brazil have reduced the participation of these goods in their imports, Mexico has increased that share. For other countries, imports of final goods have a higher proportion. Concerning the intraregional trade, the imports of intermediate goods in 2012-2013 are less than 50\% for almost all partners, except for Mexico (65.9\%), Paraguay (59.1\%) and Ecuador (55.3\%). When we consider the Association as a whole, intra-LAIA imports of intermediate goods account for $35.3 \%$, while the extra- 
LAIA imports account for $70.4 \%$ in 2012-2013. Thus, unlike what happens with exports, imports of intermediate goods are only relevant for larger partners, such as Mexico, Brazil and Argentina, suggesting that these countries are more integrated into the global chains of the automobile industry. To intraregional trade, imports of intermediate goods are less significant for all partners, suggesting, when contrasted with exports, that the level of productive coordination within the region is still low.

Table 10: Share the automotive industry intermediate goods imports in intra and extra-LAIA trade (in\%)

\begin{tabular}{|c|c|c|c|c|c|c|c|c|c|c|}
\hline \multirow[t]{2}{*}{ Countries } & \multicolumn{2}{|c|}{$2000-2002$} & \multicolumn{2}{|c|}{ 2003-2005 } & \multicolumn{2}{|c|}{$2006-2008$} & \multicolumn{2}{|c|}{ 2009-2011 } & \multicolumn{2}{|c|}{ 2012-2013 } \\
\hline & INTRA & EXTRA & INTRA & EXTRA & INTRA & EXTRA & INTRA & EXTRA & INTRA & EXTRA \\
\hline Argentina & 60.2 & 75.9 & 42.4 & 81.1 & 46.8 & 68.5 & 48.2 & 67.1 & 41.7 & 65.1 \\
\hline Bolivia & 50.7 & 30.9 & 41.0 & 21.0 & 64.9 & 11.7 & 59.0 & 100.0 & 42.0 & 19.0 \\
\hline Brazil & 41.0 & 84.9 & 67.8 & 89.3 & 31.1 & 80.4 & 21.3 & 66.2 & 23.8 & 77.0 \\
\hline Chile & 34.8 & 35.4 & 23.8 & 40.5 & 34.1 & 31.3 & 44.9 & 33.0 & 45.0 & 26.3 \\
\hline Colombia & 35.5 & 46.2 & 27.2 & 43.1 & 26.0 & 34.0 & 19.1 & 35.5 & 15.8 & 36.9 \\
\hline Ecuador & 25.5 & 42.9 & 23.8 & 37.6 & 35.1 & 30.7 & 55.8 & 29.7 & 55.3 & 37.8 \\
\hline Mexico & 33.6 & 77.8 & 27.2 & 75.0 & 46.9 & 71.2 & 60.3 & 80.3 & 65.9 & 81.3 \\
\hline Paraguay & 48.2 & 27.1 & 57.7 & 25.0 & 56.0 & 30.6 & 64.5 & 32.4 & 59.1 & 25.7 \\
\hline Peru & 52.1 & 36.3 & 49.9 & 37.8 & 53.8 & 30.2 & 51.5 & 27.1 & 43.4 & 22.9 \\
\hline Uruguay & 57.3 & 68.0 & 51.5 & 59.7 & 48.2 & 51.3 & 36.3 & 47.2 & 28.3 & 43.8 \\
\hline Venezuela & 20.4 & 27.8 & 25.0 & 31.6 & 24.7 & 34.1 & 68.4 & 86.6 & - & - \\
\hline LAIA & 40.0 & 73.6 & 36.9 & 71.8 & 39.5 & 64.9 & 38.3 & 67.9 & 35.3 & 70.4 \\
\hline
\end{tabular}

Source: Own elaboration based on data from COMTRADE.

As shown in Table 11, the share of intermediate goods in the extra-regional trade is higher than $70 \%$ in 8 of the 11 countries of LAIA, except Mexico (57\%), Uruguay (69\%) and Venezuela (17\%). In 2010, 100\% of the exports to the LAIA from Bolivia were intermediate goods, a very similar share to that observed in Venezuela. In contrast, Mexican intermediate goods exports were very low for most partners (with the exceptions of Paraguay - 61\% - and Venezuela - 90\%). In Argentina, the profile is more differentiated among its partners: the share of intermediate goods in bilateral exports are relatively low for Mercosur partners - Brazil (23\%), Paraguay (39\%) and Uruguay (20\%) - but, in return, is higher to Bolivia (74\%), Peru (77\%), Chile (81\%) and Mexico (83\%). Brazil has a high share of intermediate goods in exports, above $50 \%$ for all partners ${ }^{30}$. The participation of these goods in trade with extra-regional partners is higher than $70 \%$ in 8 of 11 countries, with the exceptions of Mexico (57\%), Uruguay (69\%) and Venezuela $(17 \%)^{31}$. The importance of intermediate goods in auto industry is related not only to the assembly and production of final goods but also for repairing activities. For those countries that don't have local production, intermediate goods are used to reparation.

\footnotetext{
30 This high level in the case of Brazil is due to the exports of CKD kits to its regional partners.

${ }^{31}$ In Venezuela, 2009 and 2010 seem to be non-standard years. On average, the share of exports of intermediate goods in the automotive industry reaches $98 \%$.
} 
Table 11: Share of exports of intermediate goods in intra-LAIA bilateral exports of the automotive industry in 2010 (\%)

\begin{tabular}{|c|c|c|c|c|c|c|c|c|c|c|c|c|c|}
\hline \multirow{2}{*}{$\begin{array}{l}\text { Export } \\
\text { country }\end{array}$} & \multicolumn{10}{|c|}{ Import country } & \multirow[b]{2}{*}{ Venezuela } & \multirow[b]{2}{*}{ LAIA } & \multirow[b]{2}{*}{ World* } \\
\hline & Argentina & Bolivia & Brazil & Chile & Colombia & Ecuador & Mexico & Paraguay & Peru & Uruguay & & & \\
\hline Argentina & - & 74.2 & 23.1 & 81.2 & 25.2 & 27.4 & 83.2 & 39.1 & 77.2 & 20.2 & 51.1 & 26.0 & 97.0 \\
\hline Bolivia & 100.0 & - & 100.0 & 100.0 & - & 100.0 & - & 100.0 & - & 100.0 & 100.0 & 100.0 & 100.0 \\
\hline Brazil & 53.0 & 87.3 & - & 85.7 & 60.9 & 83.1 & 51.1 & 77.7 & 72.0 & 58.3 & 96.2 & 56.6 & 78.0 \\
\hline Chile & 98.8 & 17.3 & 99.9 & - & 100.0 & 65.0 & 100.0 & 3.2 & 60.9 & 84.8 & 76.2 & 37.2 & 95.3 \\
\hline Colombia & 49.7 & 79.2 & 100.0 & 99.3 & - & 99.8 & 99.9 & 77.8 & 99.7 & 94.2 & 99.9 & 99.7 & 96.9 \\
\hline Ecuador & 16.8 & 100.0 & 100.0 & 99.3 & 12.4 & - & 100.0 & - & 85.2 & 100.0 & 4.8 & 9.3 & 98.1 \\
\hline Mexico & 8.2 & 25.5 & 14.6 & 9.3 & 9.2 & 7.5 & - & 61.3 & 16.7 & 15.3 & 90.1 & 12.7 & 56.9 \\
\hline Paraguay & 27.7 & 100.0 & 79.5 & 100.0 & - & 100.0 & - & - & - & 100.0 & - & 79.4 & 70.8 \\
\hline Peru & 83.3 & 89.7 & 90.0 & 96.1 & 74.6 & 49.7 & 89.9 & 100.0 & - & 0.3 & 36.2 & 83.0 & 84.5 \\
\hline Uruguay & 78.3 & 100.0 & 35.6 & 96.2 & 83.2 & - & 99.8 & 20.6 & 19.1 & - & - & 64.1 & 69.4 \\
\hline Venezuela & 100.0 & - & 100.0 & 100.0 & 99.4 & 98.9 & 100.0 & - & 100.0 & - & - & 99.7 & 17.1 \\
\hline LAIA & 47.8 & 27.3 & 22.2 & 62.2 & 30.9 & 61.2 & 54.5 & 31.1 & 60.7 & 39.5 & 73.2 & 39.6 & 58.5 \\
\hline
\end{tabular}

Source: Own elaboration based on data from COMTRADE. *World exports excluding LAIA.

\section{Concluding remarks}

Although the presence of automotive industrial parks in Latin America since the end of World War II, as a part of its industrialization through import substitution policies, only in the 90s, with the policies of exchange controls and trade liberalization, the region could reduce its technological gap relative to developed economies. In particular, with the implementation of automotive regimes and preferential trade agreements, the region become one of the most attractive regions for foreign investments in the sector.

Data about production and sales of vehicles in LAIA show that Brazil and Mexico, followed by Argentina, are the most important countries for the automotive sector. These countries together account for $97 \%$ of the vehicles produced in the region and for $83 \%$ of the LAIA's sales. With regard to foreign trade, the pattern is similar. Mexico accounts for $77 \%$ of exports and for $47 \%$ of the automotive imports from LAIA, followed by Brazil (15\% of exports and 23\% of imports) and Argentina (7\% of exports and 14\% of imports). But, despite the high weight of Mexico for the automotive trade, this trade is more directed to the extra-regional market, especially to NAFTA. Only 7\% of Mexican exports have LAIA as a destination while in Brazil $76 \%$ of exports go to the regional market.

Regarding the integration of Latin American countries in the global automotive chain, the analysis comprised two analytical tools. The first was the trade Grubel-Lloyd index. We observed a high degree of intra-industry trade in intra-LAIA trade to Brazil (0.57) and Argentina (0.56) in 2010, while Mexico has a lower grade (0.36). Regarding the degree of extra-regional integration, the situation is different. Mexico is much more integrated with extra-regional industries (0.64 in 2010) that their partners Brazil and Argentina, which showed a significant decrease of the index between 2000 and 2010.

The second tool to analyze the degree of productive integration comprised the evaluation of the weight of intermediate goods in total trade of automotive goods. We observed a significant share of the region as a supplier of intermediate goods. The participation of these goods in extra-regional exports exceeds $70 \%$ of total automotive exports in 7 of the 11 countries of the Association in the years 2012-2013. The Brazil and Argentina also have a relatively high share: 94\% and 78\%, respectively between 2000 and 2013. The intraregional exports have a much lower share of intermediate goods and, when we consider the Association in aggregate, we can observe a slight decrease of these goods in total exports of the automotive industry.

Concerning the imports, the shares look lower, but Argentina (74\% for the period average), Brazil (80\%) and Mexico (77\%) present a high participation. Considering this trend, the region might be characterized as a supplier of parts and components to the global automotive chains, suggesting a high degree of productive integration of Argentina, Brazil and Mexico with the developed economies. The pattern of regional trade characterizes these countries as exporters of finished goods for their regional partners, while the production of other partners is more concentrated in intermediate goods.

Much of the development of the Latin American automobile industry can be attributed to policies adopted by local governments, in which tariff policies assume a special role. The tariff framework of the 
region involves numerous partial scope agreements between its members. As a result, the tariffs applied to the Association partners are consistently lower than those applied to other partners. In some agreements, we can identify the intention of creating an environment conducive to productive integration between partners, including a process of industrial complementation and productive specialization.

The comparative analysis between the Grubel-Lloyd index and tariffs applied for intermediate goods reveals that intra-industry trade tend to be higher the lower is the tariff practiced. Argentina, for example, apply zero tariff to intermediate goods from Brazil, Chile and Uruguay, and those countries are exactly the partners to which the Grubel-Lloyd index is higher (0.58, 0.70 and 0.31, respectively) .

We found that there was a productive restructuring of the global auto industry, with a strong tendency to internationalization. In this context, LAIA, and especially Brazil, Mexico and Argentina, constitute attractive markets for the major companies in the sector. In Mexico, the proximity to the North American market has stimulated the sector to develop around the NAFTA agreement. In the case of Brazil and Argentina, although the Mercosur automotive policy has not been successful, the sector has increased the productive integration through bilateral agreements under LAIA. Thus, the analysis suggests that the joint production between Brazil and Argentina has increased in the automotive sector, with those countries operating as an export platform - not only for final goods, as well as for intermediate goods - for the other countries of the region.

\section{References}

ARAÚJO, J.(2013). Fragmentação da produção e competitividade internacional: o caso brasileiro. Revista Brasileira de Comércio Exterior. 115, 42 - 51, abr/jun 2013.

ASSOCIAÇÃO LATINO-AMERICANA DE INTEGRAÇÃO (LAIA). II Tratado de MontevidéuInstrumento que institui a Associação Latino-Americana de Integração (ALADI). Montevidéu: Agosto de 1980.

BORGES, C. (2011). O padrão de inserção internacional da indústria automobilística do Mercosul na década de 2000. Dissertação, Unicamp, 2011

BRAGA, M (2001). Integração econômica regional na América Latina: uma interpretação das contribuições da Cepal. (Paper presented at the XXIX Encontro Nacional de Economia, Salvador-BA).

CALANDRO, M. (2000). A indústria automobilística brasileira: integração produtiva no Mercosul, regimes automotivos e perspectivas. Indicadores Econômicos FEE, Porto Alegre, 28(1), 116-136.

CASOTTI, B. e GOLDENSTEIN, M. (2008). Panorama do setor automotivo: as mudanças estruturais da indústria e as perspectivas para o Brasil. Setor Automotivo: BNDES.

CASTILHO, M. (2012). Comércio Internacional e integração produtiva: uma análise dos fluxos comerciais dos países da ALADI. Brasília: IPEA. (Working Papers: 1705)

CHUDNOVSKY,D. e CAMPBELL, G. (1991) Argentina-Brasil: luces y sombras. (Paper presented at the $27^{\circ}$ Colóquio de IDEA: Instituto para El desarrollo de empresários em La Argentina. Buenos Aires)

COASE, R.H. (1937). The Nature of the Firm. Economica, New Series, 4(6).

DIETER, H. (2007). Transnational Production Networks in the Automobile Industry and the Function of Trade-Facilitation Measures. Notre Europe: Studies e research n 58.

DULLIEN, S. (2010). Integração Produtiva na União Européia: uma perspectiva alemã. In Integração Produtiva - caminhos para o Mercosul. Série Cadernos da Indústria ABDI. Vol XVI. Brasília. 2010.

ECLAD-CEPAL (2009). La inversión extranjera directa en América Latina y El Caribe. Santiago: Nações Unidos.

ECLAD (2013). Panorama da inserção internacional da América Latina e Caribe. CEPAL. ELMS, D. e LOW, P. (Eds) (2013) Global value chains in a changing world, World Trade Organization (WTO).

ESTEVADEORDAL, A. BLYDE, J. e SUOMINEN, K.(2013). As cadeias globais de valor são realmente globais? Políticas para acelerar o acesso dos países às redes de produção internacionais. Revista Brasileira de Comércio Exterior. 115. 6-25. abr/jun 2013. 
FUGAZZA, M. e NICITA, A. (2010). The value of preferential market acess. UNCTAD. Publication series on Policy Issues in International Trade and Commodities

GALAR, M. (2012). Competing within global value chains. ECFIN Economic Brief. 17.

GEREFFI, G.; FERNANDEZ-STARK, K. (2011) Global Value Chain Analysis: A Primer. Center on Globalization, Governance and Competitiveness, 2011

GONÇALVES, C. e VEIGA, J. (1995). A indústria automotiva brasileira no Mercosul. In São Paulo em Perspectiva. 09 (1).

HAMAGUCHI, N. (2010). “Integração Produtiva Regional no leste da Ásia”. In Integração Produtiva caminhos para o Mercosul. Série Cadernos da Indústria ABDI. Vol XVI. Brasília. 2010.

HELPMAN, E. (2011). Understanding Global Trade. Cambridge: Harvard College.

HILBERRY, R. (2011). Causes of international production fragmentation: some evidence. In Global Value Chains: Impacts and implications, 77 - 102.

HUMPHREY, J. e MEMEDOVIC, O. (2003). The global automotive industry value chain: What prospects for upgrading by developing countries. Viena: United Nations Industrial Development Organization.

JONES, R. e KIERKOWSKI, H. (1990) The role of services in production and internacional trade: a theorical framework. In: R. Jones and A. Krueger, eds., The political economy of international trade. (Blackwell's: Oxford), 31-48.

KAPLINSKI, R.; MORIS, M. (2001). Handbook for Value Chain Research. IDRC.

KIMURA, F. e ANDO, M. (2005). Two-dimensional fragmentation in East Asia: conceptual framework and empirical. International Review of Economics and finance, 17.

KOSACOFF, B. e LÓPEZ, A. (2008). América Latina y las Cadenas Globales de Valor: debilidades y pontecialidades. Revista globalización, competititividad y gobernabilidad, 2(1), Georgetown University.

MACHADO, J. (2010). Integração Produtiva: referencial analítico, experiência europeia e lições para o Mercosul. In Integração Produtiva - caminhos para o Mercosul. Série Cadernos da Indústria ABDI. Vol XVI. Brasília. 2010.

MEDEIROS, C. (2010). Integração Produtiva: A Experiência Asiática e Algumas Referencias para o Mercosul. In Integração Produtiva - caminhos para o Mercosul. Série Cadernos da Indústria ABDI. Vol XVI. Brasília. 2010.

MILBERG e WINKLER (2011) Economic and social upgrading in global production networks: Problems of theory and measurement. International Labour Review. Volume 150, Issue 3-4, pages 341-365.

NISHITATENO, S. (2012). Global Production Sharing and FDI-Trade Nexus: New Evidence from the Japanese Automobile Industry. Australia-Japan Research Centre, Crawford School of Public Policy, The Australian National University (Asia Pacific Economic Papers 397).

OLIVEIRA, S. (2014). "Cadeias Globais de Valor e os novos padres de comercio internacional: uma análise comparada das estratégias de inserção de Brasil e Canadá”. 223f. Tese. Universidade de Brasília.

OCAMPO, J. (2001). Raúl Prebisch y la agenda del desarrollo en los albores del siglo XXI, Revista de la CEPAL, 77, 25-39.

OCDE (2013). Interconnected economies: benefiting from global value chains. Retrieved: 14 de December de 2014. (From: http://www.oecd.org/sti/ind/interconnected-economies-GVCs-synthesis.pdf)

SELA (2014). "Políticas de desarrollo productivo e industrial en América Latina y El Caribe”. Caracas: SELA. Abril

SOUZA, R. A (2003) Integração Econômica Regional na América Latina. In Conjuntura \& Planejamento, Salvador: SEI, 12, 44-49.

STURGEON, T. (2013). Global Value Chains and Economic Globalization: towards a measurement framework. A report to Eurostat.

STURGEON, T. e MEMEDOVIC, O. (2011). Mapping global value chains: intermediate goods trade and strutural change in world economy. Development policy and strategic research branch, United Nations Industrial Development Organization, Viena (Working paper $n^{\circ}$ 05/2010). 
STURGEON, T. J., MEMEDOVIC, O., VAN BIESEBROECK, J. e GEREFFI, G. (2009). Globalisation of the automotive industry: main features and trends, Int. J. Technological Learning, Innovation and Development, 2(1/2), 7-24.

STURGEON, T., GEREFFI, G, GUINN, A. e ZYLBERBERG, E. (2013). O Brasil nas cadeias globais de valor: implicações para a política industrial e de comércio. Revista Brasileira de Comércio Exteriorno, 115

SUNKEL, O. Desarrollo y integración: ¿otra oportunidad para una promesa incumplida ?, Revista de la CEPAL, numero extraordinario. 1998

TAVARES, M. C. e GOMES, G. (1998) La CEPAL y la integración económica de América Latina, Revista de la CEPAL, número extraordinário.

UNCTAD. (2013) Global supply chains: trade and economic policies for developing countries . United Nations Publications.

UNCTAD. (2013b) Global Value Chains and Development: Investment and Value Added Trade in the Global Economy. United Nations Publications.

WEF (2012). The shifting geography of global value chains: implications for developing countries and trade policy. World Economic Forum: Geneva.

WOMACK, J. P., JONES, D. T. e ROSS, D. 2004. A máquina que mudou o mundo: Baseado no estudo do Massachussetts Institute of Technology sobre o futuro do automóvel. Rio de Janeiro: Elsevier, 2004. 